\author{
E. Mašić \& S. Barudanović
}

\title{
Diversity and new records of species from genus Eunotia (Bacillariophyceae, Ochrophyta) in freshwater habitats on Vranica mountain (Bosnia and Herzegovina)
}

\begin{abstract}
Mašić, E. \& Barudanović, E.: Diversity and new records of species from genus Eunotia (Bacillariophyceae, Ochrophyta) in freshwater habitats on Vranica mountain (Bosnia and Herzegovina). — Borziana 1: 15-33. 2020.

In this paper diversity and new records of species from the genus Eunotia in freshwater habitats from Vranica mountain are presented. During our research for this study 22 species were identified. Comparing our results with publications by various authors who have explored algae in Bosnia and Herzegovina, there is not any data about the presence and distribution of four species. Newly recorded species for the flora of algae of Bosnia and Herzegovina were listed as follows: Eunotia curtagrunowii, Eunotia implicata, Eunotia mucophila and Eunotia subherkiniensis. Data about identified species as well as their distribution and ecological characteristics are presented in this paper. Physical and chemical characteristics of freshwater habitats, where rare and endangered species occurred, are described. Mountain springs, streams and peatlands represent suitable habitats for species from the genus Eunotia. Since they provide optimal conditions for rare and endangered species in the future they should be included in continuous monitoring.
\end{abstract}

Key words: Algae, diatoms, diversity, freshwater habitats, conservation, monitoring.

\section{Introduction}

The genus Eunotia (Bacillariophyceae, Ochrophyta) includes freshwater species which inhabit mainly oligotrophic waters (Glushchenko \& Kulikovskiy 2017). Diatoms belonging to this genus are characterized by having short and rudimentary raphes on both valves of a cell or on only one valve for a few diatoms. Valves bent along the apical axis and dorsiventral are symmetrical to the transapical axis, or asymmetrical for a few diatoms. Terminal nodule is evident on the apex. Typically, two large plastids of plates form in the cytoplasm (Joh 2011). Numerous species of this genus are widely distributed in the world flora (Bukhtiyarova 2019). According to Guiry \& Guiry (2020), species from the genus Eunotia are widely distributed all over the world and there are 1005 species names in the 
database at present. Diatoms of the genus Eunotia occur only in freshwaters, and in oligotrophic or dystrophic waters as periphytic or benthic. They have been mainly described from the Northern Hemisphere and diverse species are commonly well represented in tropical regions - Amazonian area and other tropical regions (Joh 2011). Eunotia species are important indicators of very good ecological quality and are strongly linked to naturally acid, oligotrophic or dystrophic habitats. Some species are excellent indicators of different degrees of anthropogenic acidification (Cantonati \& al. 2017). Species from the genus Eunotia in Bosnia and Herzegovina are reported from the different microhabitats, but there is no comprehensive checklist. Data about diversity and distribution can be found in various publications (Karlinski 1896; Protić 1897, 1903, 1904, 1906, 1907, 1908, 1920 1921/1922b, 1924, 1925, 1926, 1927, 1928a, 1928b, 1928c; Gutwinski 1902; Blagojević 1966, 1974; Jerković 1985; Hafner 1991; Hafner \& Mirković 2008; Hafner \& Jasprica 2013; Hafner \& al. 2013, 2015; Kapetanović \& Hafner 2007; Kapetanović \& al. 2011; Kamberović \& Barudanović 2012; Kamberović \& al. 2013; Barudanović \& al. 2014; Dedić \& al. 2015; Karasuljić-Ibrović 2017; Duraković 2018; Mašić 2018, Tomović \& al. 2020).

The main aim of this study was to investigate the richness of diatoms from the genus Eunotia on Vranica mountain (Bosnia and Herzegovina), with two specific aims as follows:

- establishment of a comprehensive checklist of diatoms from the genus Eunotia in Bosnia and Herzegovina with a description of general data about morphology, ecology and distribution of identified taxa (Table 3);

- establishment of a database which will be used for the future monitoring of biodiversity of this very interesting group of algae.

This paper also contains notes about new records for Bosnia and Hercegovina and new distributional data for selected taxa from the genus Eunotia.

\section{Materials and Methods}

\section{Analysis of physical and chemical parameters}

Physical and chemical parameters of water were measured directly on sampling sites. Water temperature, $\mathrm{pH}$, dissolved oxygen and specific electric conductivity were measured with portable multimeter Orion Star A329, while turbidity was measured with Portable turbidimeter AQ3010 and total dissolved solids (TDS) with PCE-CM 41.

\section{Collection and processing of phytobenthos}

Live algological material was collected from five freshwater habitat types and transported to the Laboratory for the study of the systematics of algae and fungi, Department of Biology, Faculty of Science, University of Sarajevo. Samples of phytobenthos were collected from different types of substrates: epilithon, periphyton and epipelon. Sample from submerged stones was collected by scraping with a scalpel blade or brushing the upper surface of submerged stones. Periphyton samples contained non-washed parts of submerged macroalgae and macrophytes. Epipelon samples were collected from the uppermost layer of mud with a spoon or pipette aspirator. The collected material was fixed with a $4 \%$ formalin. Laboratory processing of diatoms was carried out by applying methods used by Hustedt (1930). In order to obtain pure valves of diatoms, part of the obtained material was digested with sulfuric acid $\left(\mathrm{H}_{2} \mathrm{SO}_{4}\right)$, potas- 
sium permanganate $\left(\mathrm{KMnO}_{4}\right)$ and oxalic acid $\left(\mathrm{C}_{2} \mathrm{H}_{2} \mathrm{O}_{4}\right)$. The cleaned valves of diatoms are then mounted in a Canada balsam. Species composition is estimated from the permanent slides under 1000x magnification using light microscope Best Scope 2020. The identification of diatoms was supported by the following references: Lange-Bertalot \& Metzeltin (1996) and Cantonati \& al. (2017). The nomenclature of identified diatoms species was adjusted according to the following internet base: Guiry \& Guiry 2020). Omnidia software (Lecointe \& al. 1993) version 6.0.8, was used to assess ecological and taxonomic data. Measurements of diatom frustules were taken using Omnidia database (Lecointe \& al. 1993).

\section{Study area}

The material for this study was collected from reocren springs, small creeks, streams and also from the lake and peatlands which are located on Vranica Mountain (Tab. 1). Sampling was performed during the summer and autumn seasons in 2018 and 2019. Detailed data about topography and syntaxonomic diversity on Vranica mountain are described in various publications (Redžić 2007; Drešković \& Mirić 2017). The position of the studied area is shown on the map (Fig. 1).

Table 1. The main physical characteristics of sampling sites (Sample Code: MSPR - Mountain spring, MCRE - Mountain creek, MSTR - Mountain stream, MLAK - Mountain lake, MPEA - Mountain peatlands)

\begin{tabular}{lllll}
\hline Site & $\begin{array}{l}\text { Sample } \\
\text { Code }\end{array}$ & Latitude & Longitude & Altitude \\
\hline 1 & MSPR2 & 43.97906 & 17.18250 & 823 \\
2 & MSPR4 & 43.95568 & 17.75337 & 1658 \\
3 & MSPR7 & 43.95706 & 17.74427 & 1732 \\
4 & MSPR8 & 44.00941 & 17.78703 & 1403 \\
5 & MSPR10 & 43.95346 & 17.75755 & 1675 \\
6 & MSPR11 & 43.95131 & 17.76064 & 1761 \\
7 & MCRE7 & 43.95353 & 17.75757 & 1682 \\
8 & MCRE8 & 43.95361 & 17.75761 & 1677 \\
9 & MSTR3 & 43.96792 & 17.77601 & 1214 \\
10 & MSTR4 & 43.96791 & 17.77615 & 1210 \\
11 & MSTR8 & 43.97324 & 17.78249 & 1091 \\
12 & MSTR9 & 43.97333 & 17.70276 & 1074 \\
13 & MLAK1 & 43.95846 & 17.75626 & 1636 \\
14 & MLAK5 & 43.95641 & 17.75510 & 1636 \\
15 & MLAK11 & 43.95696 & 17.75564 & 1636 \\
16 & MPEA1 & 43.95194 & 17.75807 & 1714 \\
17 & MPEA2 & 43.95192 & 17.75827 & 1714 \\
18 & MPEA3 & 43.95135 & 17.76056 & 1755 \\
19 & MPEA4 & 43.95134 & 17.76057 & 1755 \\
20 & MPEA5 & 43.95133 & 17.76061 & 1755 \\
21 & MPEA6 & 43.95131 & 17.76065 & 1755 \\
22 & MPEA7 & 43.95754 & 17.75866 & 1633 \\
23 & MPEA8 & 43.95750 & 17.75868 & 1634 \\
24 & MPEA10 & 43.95742 & 17.75880 & 1634 \\
25 & MPEA11 & 43.95137 & 17.76060 & 1761 \\
\hline
\end{tabular}




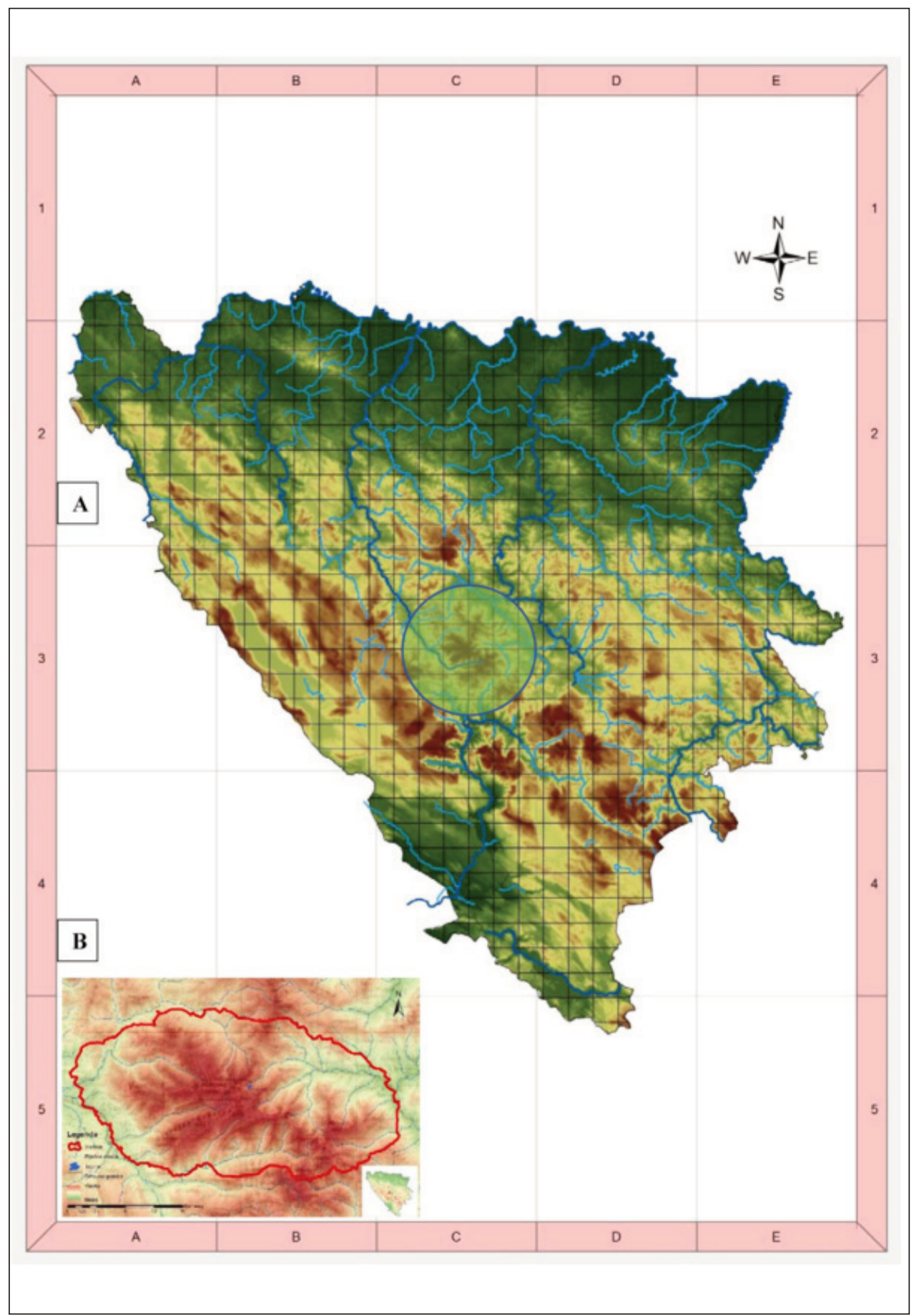

Fig. 1. Position of studied area (Vranica mountain) 


\section{Results}

\section{A. Analysis of physical and chemical parameters of water}

A comparison of the physical and chemical parameters of water in the freshwater habitat types on Vranica mountain (Tab. 2) revealed the following: the water temperature on sampling sites varied from 6.2 (site 7) to $22.20^{\circ} \mathrm{C}$ (site 13) during the period of examination. The lowest $\mathrm{pH}$ of the water was 4.16 while the highest $\mathrm{pH}$ value was 8.57 . The smallest concentration of dissolved oxygen in the water was measured at site $24\left(6.47 \mathrm{mgL}^{-1}\right)$, while the highest value was measured at site $7\left(10.85 \mathrm{mgL}^{-1}\right)$. The value of specific conductivity varied from 19.59 to $600.8 \mu \mathrm{Scm}^{-1}$. The lowest value of turbidity was measured at site 3 (0.04 NTU), while at site 17 the highest value of turbidity was measured (2.81 NTU). The value of total dissolved substance varied from 36 to $190 \mathrm{ppm}$. The results of physical and chemical parameters are presented in Table 2.

Table 2. Value of water temperature, $\mathrm{pH}$, dissolved oxygen, specific electric conductivity, turbidity and TDS [T1 - water temperature, DO - dissolved oxygen, SC - specific electric conductivity, T2 turbidity, TDS - total dissolved substance]

\begin{tabular}{llllllll}
\hline Site & $\begin{array}{l}\text { Sample } \\
\text { Code }\end{array}$ & $\begin{array}{l}\text { T1 } \\
{\left[{ }^{\circ} \mathbf{C}\right]}\end{array}$ & $\mathbf{p H}$ & $\begin{array}{l}\text { DO } \\
{\left[\mathbf{m g L}^{-1}\right]}\end{array}$ & $\begin{array}{l}\mathbf{S C} \\
{\left[\boldsymbol{\mu S c m} \mathbf{S c m}^{-1}\right]}\end{array}$ & $\begin{array}{l}\text { T2 } \\
{[\mathbf{N T U}]}\end{array}$ & $\begin{array}{l}\text { TDS } \\
{[\mathbf{p p m}]}\end{array}$ \\
\hline 1 & MSPR2 & 14.50 & 6.90 & $\mathrm{~N} / \mathrm{a}$ & 73.0 & $\mathrm{~N} / \mathrm{a}$ & 51.0 \\
2 & MSPR4 & 13.40 & 8.18 & 7.98 & $\mathrm{~N} / \mathrm{a}$ & 4.91 & $\mathrm{~N} / \mathrm{a}$ \\
3 & MSPR7 & 10.00 & 8.54 & 8.81 & 220.9 & 0.04 & 117 \\
4 & MSPR8 & 11.80 & 6.47 & 9.31 & 48.52 & 0.45 & 51.0 \\
5 & MSPR10 & 7.00 & 8.01 & 9.00 & 165.3 & 1.21 & 129 \\
6 & MSPR11 & 8.30 & 6.36 & 8.61 & 19.59 & 0.57 & 41.0 \\
7 & MCRE7 & 6.20 & 7.97 & 10.85 & 161.8 & 1.12 & $\mathrm{~N} / \mathrm{a}$ \\
8 & MCRE8 & 5.90 & 8.11 & 10.42 & 164.9 & 1.88 & $\mathrm{~N} / \mathrm{a}$ \\
9 & MSTR3 & 11.70 & 8.42 & 9.40 & 193.8 & 0.59 & 159 \\
10 & MSTR4 & 11.70 & 8.41 & 9.50 & 201.2 & 0.92 & 157 \\
11 & MSTR8 & 13.40 & 8.47 & 9.23 & 199.9 & 0.54 & 152 \\
12 & MSTR12 & 10.60 & 8.22 & 8.86 & 251.2 & 0.90 & 146 \\
13 & MLAK1 & 22.20 & 8.20 & 7.93 & 150.7 & 3.36 & N/a \\
14 & MLAK5 & 20.20 & 8.57 & 9.94 & 201.2 & 1.73 & N/a \\
15 & MLAK11 & 18.00 & 8.29 & 8.18 & 170.5 & 0.70 & 190 \\
16 & MPEA1 & N/a & N/a & N/a & N/a & N/a & N/a \\
17 & MPEA2 & 17.50 & 4.16 & 7.28 & 600.8 & 868 & 495 \\
18 & MPEA3 & 19.00 & 5.29 & 6.92 & 50.52 & 620 & 121 \\
19 & MPEA4 & 18.30 & 5.47 & 7.00 & 43.09 & 73.8 & 46.0 \\
20 & MPEA5 & 18.30 & 5.67 & 7.00 & 43.09 & 617 & 43.0 \\
21 & MPEA6 & 16.00 & 5.75 & 7.82 & 33.74 & 588 & 38.0 \\
22 & MPEA7 & 9.10 & 7.11 & 8.27 & 147.1 & 68.3 & 36.0 \\
23 & MPEA8 & 9.10 & 7.14 & 7.28 & 171.4 & 8.58 & 133 \\
24 & MPEA10 & 8.00 & 5.17 & 6.47 & 170.3 & 278 & N/a \\
25 & MPEA11 & 7.60 & 5.93 & 7.69 & 22.44 & 20.3 & 47.0 \\
\hline
\end{tabular}




\section{B. Taxonomical part}

During research for this study 22 species from the genus Eunotia were identified. Comparing results from this study with publications by various authors who have explored algae in Bosnia and Herzegovina, for four species there is not any data. Newly recorded species are: Eunotia curtagrunowii, Eunotia implicata, Eunotia mucophila and Eunotia subherkiniensis. The new species were found in reocren spring, stream and peatlands. Detailed characteristics about the identified species from the genus Eunotia, distribution and ecological preferences will be presented further in this work.

\section{Eunotia arcubus Nörpel \& Lange-Bertalot}

\section{Syn. Eunotia arcus var. bidens Grunow in Van Heurck}

Dimensions: Length 14-95 $\mu \mathrm{m}$; Width 4-9 $\mu \mathrm{m}$. Striae: 8-12/10 $\mu \mathrm{m}$. Puncta: 30-32/10 $\mu \mathrm{m}$. Distribution in freshwater habitats on Vranica mountain: Mountain lake (MLAK1, MLAK11).

Distribution in Bosnia and Herzegovina: Hafner \& Mirković 2008; Mašić 2018.

Optimal environmental conditions: Occurring in carbonate-rich, oligo- to mesotrophic lakes and springs, very rare in running waters. Studies on the occurrence of E. arcubus in springs (Cantonati \& al. 2012) and lakes on carbonate substratum suggest that E. arcubus prefers low light and very low flow conditions (Cantonati \& al. 2017).

General distribution and ecology: According to Van Dam \& al. (1994), an aquatic to aerophilic, sensitive N-autotrophic, neutrophilic, halophobe, oligosaprobe and oligomesotrophic species.

Conservation status: According to Red List (Lange-Bertalot \& Steindorf, 1996), this species is at risk $(\mathrm{G})$.

\section{Eunotia arcus Ehrenberg}

Dimensions: Length 19-115 $\mu \mathrm{m}$; Width 6-11 $\mu \mathrm{m}$. Striae: 11-14/10 $\mu \mathrm{m}$. Puncta: 30-36/10 $\mu \mathrm{m}$. Distribution in freshwater habitats on Vranica mountain: Mountain spring (MSPR4).

Distribution in Bosnia and Herzegovina: Protić 1897; Gutwinski 1902; Protić 1903; Protić 1906; Protić 1907; Protić 1908; Protiv 1921/1922b; Protić 1925; Protić 1926; Protić 1927; Protić 1928a; Protić 1928; Protić 1924; Karlinski 1896; Hafner 1991; Hafner \& Mirković 2008; Kamberović \& Barudanović 2012; Hafner \& al. 2013; Kamberović \& al. 2013; Dedić \& al. 2015; Karasuljić-Ibrović 2017; Mašić 2018.

Optimal environmental conditions: Abundant in undisturbed oligo - to dystrophic habitats (Cantonati \& al. 2017).

General distribution and ecology: Rather rare, in contrast to northern and eastern Europe and the siliceous Alps (Cantonati \& al. 2017). According to Van Dam \& al. 1994, an aquatic to aerophilic, sensitive N-autotrophic, neutrophilic, halophobe, oligosaprobe and oligo-mesotrophic.

Conservation status: According to Red List (Lange-Bertalot \& Steindorf 1996), this species is highly endangered (2).

\section{Eunotia bilunaris (Ehrenberg) Schaarschmidt}

Dimensions: Length 14-105 $\mu \mathrm{m}$; Width 3,5-5,5 $\mu \mathrm{m}$. Striae: 13-17/10 $\mu \mathrm{m}$. Puncta: 40-45/10 $\mu \mathrm{m}$. Distribution in freshwater habitats on Vranica mountain: Mountain springs (MSPR4, 
MSPR10, MSPR11), mountain stream (MSTR3, MSTR4, MSTR8) and mountain peatlands (MPEA5).

Distribution in Bosnia and Herzegovina: Kapetanović \& al. 2011; Hafner \& al. 2013; Barudanović \& al. 2014; Dedić \& al. 2015; Duraković 2018; Mašić 2018.

Optimal environmental conditions: Oligo- to dystrophic, but oligosaprobic freshwater habitats (Cantonati \& al. 2017).

General distribution and ecology: Distributed in wide range of conditions, from acidic (due to humic acids) to well-buffered alkaline waters (Cantonati \& al. 2017). According to Van Dam \& al. (1994), an aquatic to aerophilic, tolerant $\mathrm{N}$-autotrophic, indifferent (euryionic), oxybiontic ( $75 \%$ sat.), oligohalobous, $\beta$-mesosaprobe and indifferent.

Conservation status: According to Red List (Lange-Bertalot \& Steindorf, 1996), this species is not endangered (?).

Eunotia boreoalpina Lange-Bertalot et Nörpel-Schempp in Lange-Bertalot \& Metzeltin Syn. Eunotia incisa ,boreoalpina" - population in Krammer \& Lange-Bertalot

Dimensions: Length 12-15 $\mu \mathrm{m}$; Width 4-6 $\mu \mathrm{m}$. Striae: 13-17/10 $\mu \mathrm{m}$. Puncta: 45-50/10 $\mu \mathrm{m}$. Distribution in freshwater habitats on Vranica mountain: Mountain peatlands (MPEA2, MPEA4, MPEA6, MPEA11).

Distribution in Bosnia and Herzegovina: Tomović \& al. (2020).

Optimal environmental conditions: An indicator of low-alkalinity seepage and pool springs on siliceous substrata (Cantonati \& al. 2012 in Cantonati \& al. 2017).

General distribution and ecology: Scattered but locally abundant in mountains siliceous substrata (Cantonati \& al. 2012).

Conservation status: According to Red List (Lange-Bertalot \& Steindorf 1996), this species is not classified $(\mathrm{z})$.

\section{Eunotia cf. curtagrunowii Nörpel-Schempp \& Lange-Bertalot in Lange-Bertalot \& Metzeltin}

Dimensions: Length 13-45 $\mu \mathrm{m}$; Width 6-8,5 $\mu \mathrm{m}$. Striae: 9-14/10 $\mu \mathrm{m}$. Puncta: 27-32 (35)/10 $\mu \mathrm{m}$. Distribution in freshwater habitats on Vranica mountain: Mountain creek (MCRE7, MCRE8). Distribution in Bosnia and Herzegovina: First record for Bosnia and Herzegovina.

\section{Eunotia exigua (Brébisson) Rabenhorst}

Dimensions: Length 6-30 (50) $\mu \mathrm{m}$; Width 3-4 $\mu \mathrm{m}$. Striae: 19-14/10 $\mu \mathrm{m}$. Puncta: 45-50/10 $\mu \mathrm{m}$. Distribution in freshwater habitats on Vranica mountain: Mountain spring (MSPR11) and mountain peatlands (MPEA4, MPEA5, MPEA6, MPEA11).

Distribution in Bosnia and Herzegovina: Protić 1897; Gutwinski 1902; Protić 1926; Kapetanović \& al. 2011; Hafner \& al. 2013; Duraković 2018.

Optimal environmental conditions: Wide ecological range from freshwater environments acidified by inorganic acid to minerotrophic fens in humid acids, spring, and mountain streams at $\mathrm{pH}$ values from 2 to 7 . It can reach important relative abundances in the presence of high concentration of both naturally-occurring and anthropogenic sulphates (Alles $\&$ al. 1991). Desiccation tolerant (Cantonati \& al. 2017).

General distribution and ecology: Very frequent and often abundant everywhere (Cantonati \& al. 2017). According to Van Dam \& al. (1994), an aquatic to aerophilic, tolerant N-autotrophic, 
acidobiontic, oxybiontic (75\% sat.), oligohalophobous, $\alpha$-mesosaprobe and indifferent. Conservation status: According to Red List (Lange-Bertalot and Steindorf 1996), this species is not classified (?).

\section{Eunotia glacialifalsa Lange-Bertalot in Krammer \& Lange-Bertalot} Syn. Eunotia glacialis Meister sensu Krammer \& Lange-Bertalot 1991 pro parte, Eunotia gracilis Ehrenberg sensu Hustedt et auct. nonnull.

Dimensions: Length 40-250 $\mu \mathrm{m}$; Width 4,5-7 $\mu \mathrm{m}$. Striae: 8,5-10/10 $\mu \mathrm{m}$. Puncta: 25-28/10 $\mu \mathrm{m}$. Distribution in freshwater habitats on Vranica mountain: Mountain peatlands (MPEA1).Distribution in Bosnia and Herzegovina: Protić 1897; Gutwinski 1902; Protić 1906; Protić 1924; Protić, 1925; Protić 1926; Protić 1927.

Optimal environmental conditions: Electrolyte-poor acidic, as well bicarbonate-buffered alkaline, oligotrophic usually standing freshwaters (Cantonati \& al. 2017).

General distribution and ecology: Scattered to relatively frequent in central Europe, never really abundant (Cantonati \& al. 2017).

Conservation status: According to Red List (Lange-Bertalot \& Steindorf 1996), for this species there is not enough data.

\section{Eunotia glacialis Meister}

Dimensions: Length 60-160 $\mu \mathrm{m}$; Width 7-12 $\mu \mathrm{m}$. Striae: 10-12/10 $\mu \mathrm{m}$. Puncta: 28-30/10 $\mu \mathrm{m}$. Distribution in freshwater habitats on Vranica mountain: Mountain spring (MSPR8).

Distribution in Bosnia and Herzegovina: Kapetanović \& al. 2011; Hafner \& al. 2013.

Optimal environmental conditions: Electrolyte-poor, weakly acid, undisturbed habitats (Cantonati \& al. 2017).

General distribution and ecology: Rare in mountains (Cantonati \& al. 2017). According to Van Dam \& al. (1994), an aquatic to aerophilic, sensitive N-autotrophic, acidophilic, polyoxybiontic (100\% sat.), halophobe, oligosaprobe and oligo-mesotrophic.

Conservation status: According to Red List (Lange-Bertalot \& Steindorf 1996), this species is at risk $(\mathrm{G})$.

\section{Eunotia cf. implicata Nörpel-Schempp, Alles et Lange-Bertalot}

Dimensions: Length 18-48 $\mu \mathrm{m}$; Width 3-6 $\mu \mathrm{m}$. Striae: 14-20/10 $\mu \mathrm{m}$. Puncta: 35-40/10 $\mu \mathrm{m}$. Distribution in freshwater habitats on Vranica mountain: Mountain stream (MSTR3) and mountain peatland (MPEA7).

Distribution in Bosnia and Herzegovina: First record for Bosnia and Herzegovina.

\section{Eunotia incisa Gregory}

Dimensions: Length 10-56 $\mu \mathrm{m}$; Width 3-7 $\mu \mathrm{m}$. Striae: 16-22/10 $\mu \mathrm{m}$. Puncta: 40-45/10 $\mu \mathrm{m}$. Distribution in freshwater habitats on Vranica mountain: Mountain peatlands (MPEA3, MPEA11).

Distribution in Bosnia and Herzegovina: Kapetanović \& Hafner 2007.

Optimal environmental conditions: Electrolyte-poor, oligo- to dystrophic freshwater habitats (Cantonati \& al. 2017).

General distribution and ecology: One of the most frequent Eunotia - species, often very abundant in suitable habitats (Cantonati \& al. 2017). According to Van Dam \& al. (1994), 
an aquatic to aerophilic, sensitive $\mathrm{N}$-autotrophic, acidophilic, polyoxybiontic, halophobe, oligosaprobe and oligotrophic.

Conservation status: According to Red List (Lange-Bertalot \& Steindorf 1996), for this species risk is not estimated $(*)$.

\section{Eunotia minor (Kützing) Grunow in Van Heurck}

Dimensions: Length 16-62 (73) $\mu \mathrm{m}$; Width 4-8 $\mu \mathrm{m}$. Striae: 9-16/10 $\mu \mathrm{m}$. Puncta: (35) 40-45/10 $\mu \mathrm{m}$.

Distribution in freshwater habitats on Vranica mountain: Mountain lake (MLAK5).

Distribution in Bosnia and Herzegovina: Protić 1897; Protić 1903; Blagojević, 1966; Blagojević 1974; Kapetanović \& al. 2011; Barudanović \& al. 2014; Karasuljić-Ibrović 2017; Duraković 2018; Mašić 2018.

Optimal environmental conditions: Wide ecological amplitude, from electrolyte-poor, dystrophic mire habitats to circumneutral springs and streams on siliceous bedrock or on sandy soils, from high mountains to lowlands (Cantonati \& al. 2017).

General distribution and ecology: One of the most frequent Eunotia species, often found with high mountains to the lowlands (Cantonati \& al. 2017). According to Van Dam \& al. (1994), an aerophilic, acidophilic, halophobe and oligosaprobe.

Conservation status: According to Red List (Lange-Bertalot \& Steindorf 1996), for this species risk is not estimated $(*)$.

Eunotia cf. mucophila (Lange-Bertalot et Nörpel) Lange-Bertalot in Metzletin, Lange-Bertalot \& Garcia-Rodríguez)

Syn. Eunotia bilunaris var. mucophila Lange-Bertalot et Nörpel in Alles \& al.

Dimensions: Length 15-70 $\mu \mathrm{m}$; Width 2-3 $\mu \mathrm{m}$. Striae: 20-28/10 $\mu \mathrm{m}$. Puncta: 40-45/10 $\mu \mathrm{m}$. Distribution in freshwater habitats on Vranica mountain: Mountain peatland (MPEA2).

Distribution in Bosnia and Herzegovina: First record for Bosnia and Herzegovina.

\section{Eunotia nymanniana Grunow in Van Heurck}

\section{Syn. Eunotia steineckei Petersen 1950}

Dimensions: Length 15-55 $\mu \mathrm{m}$; Width 2,5-3,4 $\mu \mathrm{m}$. Striae: 17-21/10 $\mu \mathrm{m}$. Puncta: 40-45/10 $\mu \mathrm{m}$. Distribution in freshwater habitats on Vranica mountain: Mountain peatlands (MPEA1, MPEA2, MPEA8, MPEA10).

Distribution in Bosnia and Herzegovina: Kapetanović \& al. 2011.

Optimal environmental conditions: Occuring with other small-cell Eunotia species in undisturbed and slightly disturbed, electrolyte-poor, weakly acid (not ombrotrophic) habitats on siliceous bedrock (Cantonati \& al. 2017).

General distribution and ecology: Possible under recorded in the past as it was often confused with E. exigua and E. tenella. Widely distributed and locally abundant (Cantonati \& al. 2017). According to Van Dam \& al. (1994), an aquatic to aerophilic, sensitive Nautotrophic, acidophilic, halophobe, oligosaprobe and oligotrophic.

Conservation status: According to Red List (Lange-Bertalot \& Steindorf 1996), this species is endangered (3). 


\section{Eunotia paludosa Grunow}

Dimensions: Length 6-45 $\mu \mathrm{m}$; Width 1,8-3,5 $\mu \mathrm{m}$. Striae: 18-25/10 $\mu \mathrm{m}$. Puncta: c. 40/10 $\mu \mathrm{m}$. Distribution in freshwater habitats on Vranica mountain: Mountain spring (MSPR11), mountain lake (MLAK1) and mountain peatlands (MPEA2, MPEA4, MPEA6, MPEA7, MPEA8, MPEA10, MPEA11). Distribution in Bosnia and Herzegovina: Karlinski 1896; Gutwinski 1902; Kapetanović \& al. 2011; Duraković 2018.

Optimal environmental conditions: Ombrotrophic raised-bog habitats. Can be very abundant in such habitats. Sporadic in minerotrophic biotopes with Sphagnum where it is associated with different dystraphentis Eunotia species (e.g. E. bilunaris). Strongly associated with the presence of Sphagnum spp. (Cantonati \& al. 2011 in Cantonati \& al. 2017).

General distribution and ecology: Scatterd records, due to the loss of suitable habitats (Cantonati \& al. 2017). According to Van Dam \& al. (1994), an neutrophilic, halophilic and oligosaprobe.

Conservation status: According to Red List (Lange-Bertalot \& Steindorf 1996), this species is in declining (V).

\section{Eunotia praerupta Ehrenberg}

\section{Syn. Eunotia praerupta var. inflata Grunow in Van Heurck}

Dimensions: Length 28-105 $\mu \mathrm{m}$; Width 10-18 $\mu \mathrm{m}$. Striae: 5.5-8 (12)/10 $\mu \mathrm{m}$. Puncta: 27-32/10 $\mu \mathrm{m}$.

Distribution in freshwater habitats on Vranica mountain: Mountain stream (MSTR4).

Distribution in Bosnia and Herzegovina: Gutwinski 1902; Protić, 1920; Protić 1927; Hafner 1991; Kapetanović \& Hafner 2007; Kapetanović \& al. 2011; Hafner \& Jasprica 2013; Hafner \& al. 2013; Dedić \& al. 2015; Hafner \& al. 2015.

Optimal environmental conditions: Mainly in mountains, never abundant, in undisturbed, oligo-dystrophic, electrolyte-poor habitats on silicieous bedrock (Cantonati \& al. 2017).

General distribution and ecology: Rather rare (Cantonati \& al. 2017). According to Van Dam \& al. (1994), an aquatic to aerophilic, sensitive N-autotrophic, acidophilic, polioxybiontic (100\% sat), halophobe, oligosaprobe and oligo-mesotrophic.

Conservation status: According to Red List (Lange-Bertalot \& Steindorf 1996), this species is endangered (3).

\section{Eunotia rhomboidea Hustedt}

Dimensions: Length 10-35 $\mu \mathrm{m}$; Width 2,5-5 $\mu \mathrm{m}$. Striae: 13-19/10 $\mu \mathrm{m}$. Puncta: 40-45/10 $\mu \mathrm{m}$. Distribution in freshwater habitats on Vranica mountain: Mountain spring (MSPR11), mountain stream (MSTR12), mountain lake (MLAK1, MLAK5, MLAK11) and mountain peatlands (MPEA3, MPEA4, MPEA5, MPEA6, MPEA11).

Distribution in Bosnia and Herzegovina: Duraković 2018; Mašić 2018.

Optimal environmental conditions: Acidic minerotrophic fens, electrolyte-poor heathlandspool, springs and strems and siliceous bedrock (Cantonati \& al. 2017).

General distribution and ecology: Regionally very frequent, and often abundant (Cantonati \& al. 2017). According to Van Dam \& al. (1994), an aquatic to aerophilic, sensitive N-autotrophic, acidophilic, polyoxybiontic (100\% sat.), halophobe, oligosaprobe and oligotrophic.

Conservation status: According to Red List (Lange-Bertalot \& Steindorf 1996), this species is in declining (V). 


\section{Eunotia soleirolii (Kützing) Rabenhorst}

Dimensions: Length 15-135 $\mu \mathrm{m}$; Width 5-8 $\mu \mathrm{m}$. Striae: 7-12 (16)/10 $\mu \mathrm{m}$. Puncta: 24-25/10 $\mu \mathrm{m}$. Distribution in freshwater habitats on Vranica mountain: Mountain Spring (MSPR2, MSPR7, MSPR8).

Distribution in Bosnia and Herzegovina: Protić 1920.

Optimal environmental conditions: Undisturbed or slightly disturbed, oligo- to weakly eutrophic, not only electrolyte-poor, but usually weakly acidic habitats, for instance minerotrophic fens. Often associated with E. pectinalis (Cantonati \& al. 2017).

General distribution and ecology: Frequent and occasionally abundant (Cantonati \& al. 2017). According to Van Dam \& al. (1994), an aquatic to aerophilic, tolerant N-autotrophic, neutrophilic, polyoxybiontic (100\% sat.), halophobe, $\beta$-mesosaprobe and oligotrophic. Conservation status: According to Red List (Lange-Bertalot \& Steindorf 1996), this species is at risk $(\mathrm{G})$.

\section{Eunotia cf. subherkiniensis Lange-Bertalot in Lange-Bertalot, Bak \& Witkowski} Syn. Eunotia praerupta var. bigibba (Kützing) Grunow sensu Krammer \& Lange-Bertalot Dimensions: Length 10-30 $\mu \mathrm{m}$; Width 5-8 $\mu \mathrm{m}$. Striae: 12-15/10 $\mu \mathrm{m}$. Puncta: c. 40/10 $\mu \mathrm{m}$. Distribution in freshwater habitats on Vranica mountain: Mountain creek (MCRE8). Distribution in Bosnia and Herzegovina: First record for Bosnia and Herzegovina.

\section{Eunotia tenella (Grunow) Hustedt in A. Schmidt \& al.}

Dimensions: Length 7-28 $\mu \mathrm{m}$; Width 3-4,5 $\mu \mathrm{m}$. Striae: 14-16/10 $\mu \mathrm{m}$. Puncta: 45-50/10 $\mu \mathrm{m}$. Distribution in freshwater habitats on Vranica mountain: Mountain stream (MSTR4) and mountain peatland (MPEA11).

Distribution in Bosnia and Herzegovina: Protić 1927; Protić 1928; Jerković 1985; Hafner \& Jasprica, 2013; Hafner \& al. 2013; Duraković 2018; Mašić 2018.

Optimal environmental conditions: Undisturbed, electrolyte-poor, oligo- to dystrophic habitats. Characteristic species of low-alkalinity seepage and pool springs on siliceous substrata (Cantonati \& al. 2012 in Cantonati \& al. 2017).

General distribution and ecology: Frequent (Cantonati \& al. 2017). According to Van Dam $\&$ al. (1994), an aquatic to aerophilic, sensitive $\mathrm{N}$-autotrophic, acidophilic, polyoxybiontic (100\% sat.), halophobe, oligosaprobe and oligotrophic.

Conservation status: According to Red List (Lange-Bertalot \& Steindorf 1996), this species is in declining $(\mathrm{V})$.

\section{Eunotia tetraodon Ehrenberg}

Dimensions: Length 24-70 $\mu \mathrm{m}$; Width 9-24 $\mu \mathrm{m}$. Striae: 6-12/10 $\mu \mathrm{m}$. Puncta: $24-35 / 10 \mu \mathrm{m}$. Distribution in freshwater habitats on Vranica mountain: Mountain creek (MCRE7) and mountain peatlands (MPEA3, MPEA4, MPEA5, MPEA6, MPEA11).

Distribution in Bosnia and Herzegovina: Karlinski 1896; Gutwinski 1902; Protić 1906.

General distribution and ecology: According to Van Dam \& al. (1994), an aquatic to aerophilic, sensitive N-autotrophic, acidophilic, polyoxybiontic (100\% sat.), halophobe, oligosaprobe and oligotrophic.

Conservation status: According to Red List (Lange-Bertalot \& Steindorf 1996), this species is highly endangered (2). 


\section{Eunotia triodon Ehrenberg}

Dimensions: Length 25-100 $\mu \mathrm{m}$; Width 13-22 $\mu \mathrm{m}$. Striae: 15-18/10 $\mu \mathrm{m}$. Puncta: 21-28/10 $\mu \mathrm{m}$.

Distribution in freshwater habitats on Vranica mountain: Mountain peatland (MPEA1).

Distribution in Bosnia and Herzegovina: Protić 1904.

Conservation status: According to Red List (Lange-Bertalot \& Steindorf 1996), this species is threatened of extinction (1).

\section{Eunotia valida Hustedt}

\section{Syn. Eunotia glacialis sensu Krammer et Lange-Bertalot 1991 pro parte}

Dimensions: Length 20-115 $\mu \mathrm{m}$; Width 4-6 $\mu \mathrm{m}$. Striae: 11-15/10 $\mu \mathrm{m}$. Puncta: 30-34/10 $\mu \mathrm{m}$.

Distribution in freshwater habitats on Vranica mountain: Mountain spring (MSPR11) and mountain peatlands (MPEA3, MPEA4, MPEA5, MPEA6, MPEA11).

Distribution in Bosnia and Herzegovina: Hafner \& al. 2013.

Optimal environmental conditions: Electrolyte-poor, oligo- to dystrophic freshwater hbitats, rarer also in calcium-bicarbonate-buffered but invariably oligosaprobic inland waters (Cantonati \& al. 2017).

General distribution and ecology: Rather frequent, locally moderately abundant (Cantonati \& al. 2017). According to Van Dam \& al. (1994), an aquatic to aerophilic, sensitive N-autotrophic, acidophilic, polyoxybiontic (100\% sat.), halophobe, oligosaprobe and oligo-mesotrophic.

Conservation status: According to Red List (Lange-Bertalot \& Steindorf 1996), this species is at risk $(G)$.

\section{Ecological part}

During our study, 22 species from this genus were identified. Newly recorded species for the flora of algae of Bosnia and Herzegovina are: E. curtagrunowii, E. implicata, E. mucophila and E. subherkiniensis. By comparing ecological data (Van Dam \& al. 1994) for all identified species from the genus Eunotia we can conclude that freshwater habitats on Vranica mountain are inhabited by aquatic to aerophilic, sensitive $\mathrm{N}$-autotrophic, neutrophilic, polyoxybiontic (100\% sat.), halophobe, oligosaprobe and oligomesotrophic species (Electronic Supplementary File 1). Our study also revealed that these habitat types serve as an optimal ecological niche for certain rare and endangered species, as follows: E. triodon, E. arcus, E. subherkiniensis, E. tetraedon, E. nymanniana, E. praerupta, E. arcubus, E. curtagrunowii, E. glacialis, E. implicata, E. mucophila, E. soleirolii and E. valida.

\section{Discussion}

Despite the effort to significantly reduce biodiversity loss by 2010, recent research has confirmed the extinction of several plant and animal species listed as endangered in the IUCN Red Lists, while allochthonous taxa are increasing globally (Falasco \& Bona 2011).

From the literature data, it can be concluded that freshwater oligotrophic habitats which are distributed in the high mountain are very fragile ecosystem types and from that point of view they must be included in a different monitoring program. At the local level, the main threats to this type of habitats include: habitat reduction due to the increase of pastures, the establishment of artificial snow basins, and the construction of roads and infra- 


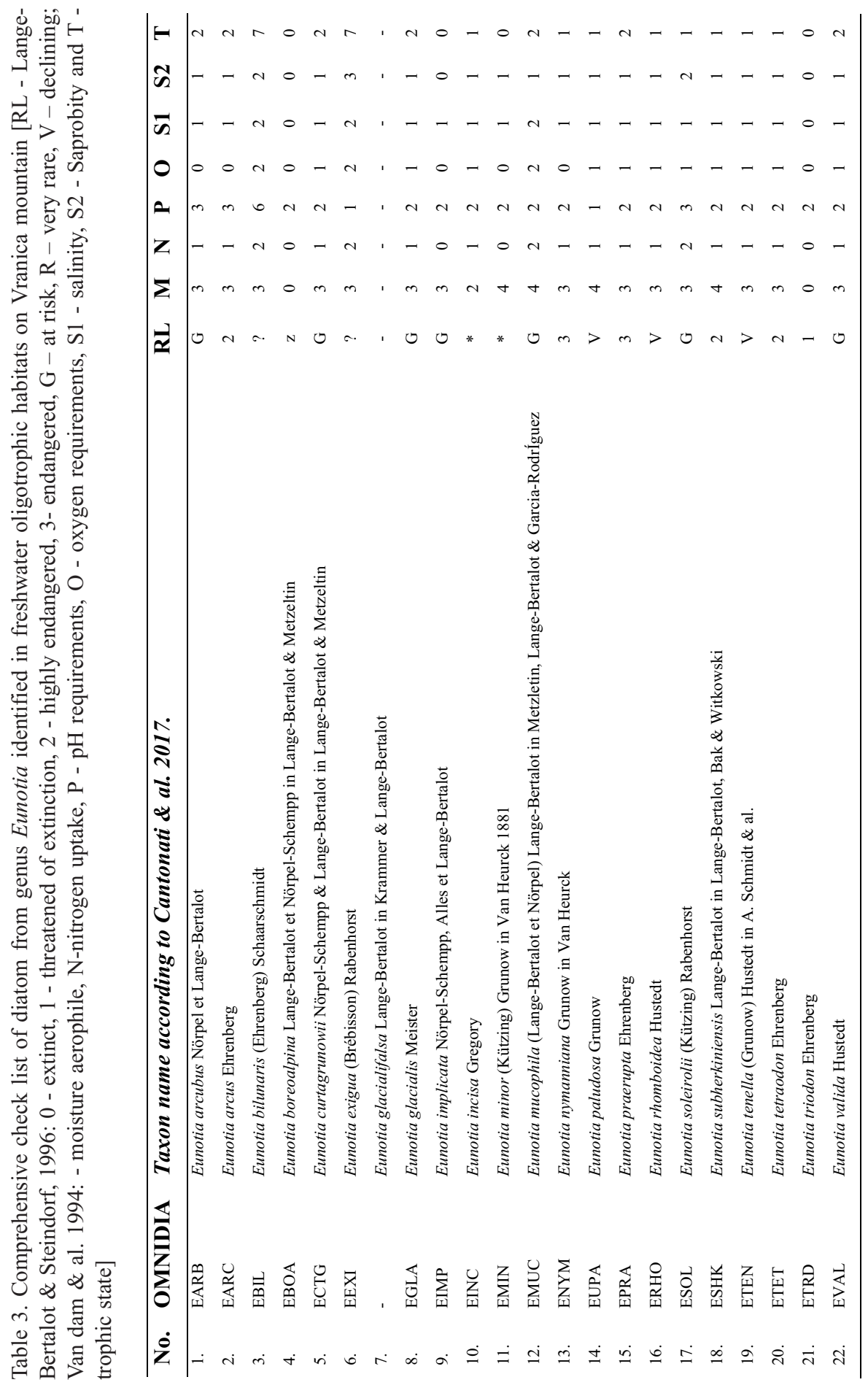


structure. From a global point of view, an increase in temperature, lengthening of the growing season, habitat fragmentation, and alteration of the snow-free period are the most important environmental factors affecting high-mountain ecosystems. As far as climatic warming and global changes are concerned, mountain regions are among the most potentially vulnerable areas, thus being strongly affected by species loss (Falasco \& al. 2012).

Algae from the genus Eunotia inhabit mainly specific habitat types on mountain areas. These are primarily springs, streams, and their diversity reach in peatland ecosystems (Cantonati \& al. 2017).

For the purposes of this paper, the research was carried out in the area of Vranica mountain. The presence of 22 species from the genus Eunotia was determined during this study. In addition to widespread species, rare and endangered species have been identified, as well as new species for the algae flora of Bosnia and Herzegovina.

Taxonomic reviews of algae from the genus Eunotia for the Balkan Peninsula are scarce. Relevant data can be found in the publications of Pavlov \& Levkov (2013) and Krizmanić \& al. (2015).

Authors Pavlov \& Levkov (2013) determined the presence of 53 species from the genus Eunotia for the algal flora of Macedonia, while authors Krizmanić \& al. (2015) determined the presence 18 species for the algae flora of Serbia.

Krizmanić \& al. (2015) found that the $\mathrm{pH}$ value at the investigated localities ranged from 5.46 to 6.50 , while the values for electrical conductivity ranged from 231 to 302 $\mu \mathrm{Scm}^{-1}$. By comparing the above results with our research, it can be concluded that the values of $\mathrm{pH}$ and electrical conductivity are slightly higher than the values of physical and chemical parameters measured in Serbia. According to the literature, the waters inhabited by species of the genus Eunotia are characterized by a low to moderate concentration of electrolytes, and the $\mathrm{pH}$ value varies from acidic to neutral (Krizmanic \& al. 2015).

The authors of Oritz-Lerin \& Cambra (2007) found that $\mathrm{pH}$ value and electrolyte composition are the main factors for the distribution of species of this genus, while the temperature of the water has no significant effect (Krizmanić \& al. 2015).

New species for the algal flora of Bosnia and Herzegovina from the genus Eunotia are: E. curtagrunowii, E. implicata, E. mucophila and E. subherkiniensis. Their basic ecological characteristics are given in the continuation of the paper.

E. curtagrunowii is moderately abundant in undisturbed, oligo- to dystrophic, electrolyte-poor, but not ombrotrophic, habitats (Cantonati \& al. 2017).

According to Van Dam \& al. (1994), this species is aquatic to aerophilic, sensitive $\mathrm{N}$-autotrophic, acidophilic, polyoxybiontic (100\% sat.), halophobe, oligosaprobe, and oligo-mesotrophic.

According to Red List (Lange-Bertalot \& Steindorf 1996), this species is at risk (G). The species was identified in two localities in mountain creeks.

E. implicata inhabited undisturbed, electrolyte-poor and oligo to dystrophic running waters. Rare in standing freshwater environments (Cantonati \& al. 2017).

According to Van Dam \& al. (1994), this species is aquatic to aerophilic, acidophilic and halophobe.

According to Red List (Lange-Bertalot \& Steindorf 1996), this species is at risk (G). The species was identified in mountain creek, and in mountain peatland. 
E. mucophila is widely distributed in the Northern Hemisphere as well as in Central Europe (Cantonati \& al. 2017).

According to Van Dam \& al. (1994), this species is aerophilic, tolerant N-autotrophic, acidophilic, oxybiontic (75\% sat.), oligohalobous, oligosaprobe and oligo-mesotrophic.

According to Red List (Lange-Bertalot \& Steindorf 1996), this species is at risk (G). Optimal environmental conditions are peatlands and similar habitats with Sphagnum ssp. dystraphentic; locally abundant (Cantonati \& al. 2017).

The species was identified in one locality in mountain peatland. E. subherkiniensis is rather rare, but occasionally moderately abundant (Cantonati \& al. 2017).

According to Van Dam \& al. (1994), this species is aerophilic, sensitive N-autotrophic, acidophilic, polyoxybiontic (100\% sat.), halophobe, oligosaprobe and oligotrophic. This species inhabited undisturbed electrolyte-poor streams and lakes that are acid due to the presence of humic acid (Cantonati \& al. 2017).

According to Red List (Lange-Bertalot \& Steindorf 1996), this species is highly endangered (2). The species was identified in one locality in mountain creeks.

\section{Conclusions}

Based on the conducted research, it can be concluded that the freshwater habitats in the area of Vranica mountain provide ideal conditions for different algal groups. Among them, the most important are diatoms from the genus Eunotia. In total 22 species from this genus were found. A total of 13 rare and endangered species of diatoms and four new species of algae from the genus Eunotia for Bosnia and Hercegovina were found, as follows: E. curtagrunowii, E. implicata, E. mucophila and E. subherkiniensis. In terms of autecological characteristics, and taking into account all identified species, it can be concluded that the identified species indicate the ecological conditions of the habitats in which they were found. Species from the genus Eunotia which are found in the freshwater habitats in the area of Vranica mountain are aquatic to aerophilic, sensitive $\mathrm{N}$-autotrophic, neutrophilic, polyoxybiontic (100\% sat.), halophobe, oligosaprobe and oligomesotrophic. Habitats, where rare and endangered species have been identified, are today under pronounced local and global pressures. In order to protect them in the future, it is necessary to establish continuous monitoring of the ecological conditions of these extremely valuable habitat types, but also the species that inhabit them.

\section{Acknowledgments}

I would like to thank the anonymous reviewer for suggestions and comments.

\section{Fundings}

This study is a part of a project entitled "Conservation of freshwater habitat types on Vranica mountain and establishment of long-term monitoring of biodiversity" which is funded by Rufford Foundation (ID 24578-1). 


\section{References}

Alles, E., Nörpel-Schempp, M. \& Lange-Bertalot, H. 1991: Zur Systematic und Ökologie characteristischer Eunotia - Arten (Bacillariophyceae) in elektrolytarmen Bachoberläufen. [On the systematic and ecology of characteristic Eunotia species (Bacillariophyceae) in low-electrolyte stream overflows]. - Nova Hedwigia 53: 130-137.

Barudanović, S., Macanović, A. \& Mašić, E. 2014: Monitoring biodiverziteta nešumskih fitocenoza na području spomenika prirode „Vrelo Bosne“ i biodiverziteta šumskih ekosistema na području spomenika prirode „Skakavac “. [Monitoring of bidiversity non-forest phytocenoses on area of Natural monument "Vrelo Bosne" and biodiversity of forest ecosystems on area of Natural monument "Skakavac"]. Centar za ekologiju i prirodne resurse - Akademik Sulejman Redžić. Prirodno-matematički fakultet, Univerzitet u Sarajevu. Elaborat.

Blagojević, S. 1966. Prilog poznavanju algi kraških izvorišta u Bosni i Hercegovini. I. Chrysophyceae, Xanthophyceae, Bacillariophyceae. [Contribution to the knowledge of alge in springs in Bosnia and Herzegovina. I. Chrysophyceae, Xanthophyceae, Bacillariophyceae]. Godišnjak, Biološkog. Inst. Sarajevo 29: 5-22.

Blagojević, S. 1974. Struktura perifitona u otvorenim uređajima vodovoda na dva krška izvorišta. [Structure of periphytons in open water supply devices at two karst springs]. - Godišnjak Biol. Inst. 27: 77-91.

Bukhtiyarova, L.N. 2019: The genus Eunotia Ehrenb. (Bacillariophyta) in the Cheremsky Nature Reserve, Ukrainian Polissya, and refined terminology relevant to the raphe system morphology. - Phyto Keys 128: 1-31.

Cantonati, M. \& Lange-Bertalot, H. 2011: Diatom monitors of close-to-pristine, very-low alkalinity habitats: three new Eunotia species from springs in Nature Parks of the south-eastern Alps. J. Limnol 70: 209-221. https://doi.org/10.4081/jlimnol.2011.209

Cantonati, M., Kelly, G. M., Lange-Bertalot, H. 2017: Freshwater Benthic Diatoms of Central Europe: Over 800 Common Species Used in Ecological Assesment. English edition with updated taxonomy and added species. - Königstein.

Cantonati, M., Angeli, N., Bertuzzi, E., Spitale, D. \& Lange-Bertalot, H. 2012: Diatoms in springs of the Alps: spring types, environmental determinants, and substratum. - Freshwater Sci. 31: 499-524. https://doi.org/10.1899/11-065.1

Dedić, A., Plenković-Moraj, A., Borojević-Kralj, K. \& Hafner D. 2015: The first report on periphytic diatoms on artificial and natural substrate in the karstic spring Bunica, Bosnia and Herzegovina. - Acta Bot. Croat. 74(2): 393-406. https://doi.org/10.1515/botcro-2015-0029

Drešković, N. \& Mirić, R. 2017: Regionalna geografija Bosne i Hercegovine. [Regional geography of Bosnia and Herzegovina]. Univerzitet u Sarajevu, Prirodno-matematički fakultet. pp 1-439.

Duraković, D. 2018: Diverzitet algi u ekosistemu tresetišta na planini Zvijezdi. [Diversity of algae in ecosystems on Zvijezda mountain]. Završni rad drugog ciklusa. Univerzitet u Sarajevu. Prirodno-matematički fakultet.

Glushchenko, A.M. \& Kulikovskiy, M.S. 2017: Taxonomy and distribution of the genus Eunotia Ehrenberg in aquatic ecosystems of Vietnam. - Inland Water Biol. 10(2): 130-139. https://doi.org/10.1134/S1995082917020055

Guiry, M. D. \& Guiry, G. M. 2020: AlgaeBase. - http://www.algaebase.org [Last Accessed 27.4.2020].

Gutwinski, R. 1902. O algama, sakupljenim u okolici travničkoj. [About algae collected in the Travnik area]. - Glasnik Zemaljskog Muz. Bosni Hercegovini 14: 69-82.

Falasco, E. \& Bona, F. 2011. Diatom community biodiversity in an Alpine protected area: a study in the Maritime Alps Natural Parks. - J. Limnol. 70: 157-167. https://doi.org/10.4081/jlimnol.2011.157 
Falasco, E., Ector, L., Ciaccio, E., Hoffmann, L. \& Bona, F. 2012: Alpine freshwater ecosystems in a protected area: a source of diatom diversity. - Hydrobiologia 695(1): 233-251. https://doi.org/10.1007/s10750-012-1114-0

Hafner, D. \& Jasprica, N. 2013: The composition of epiphytic diatoms (Bacillariophyta) on Charophyceae in the Dinaric karstic ecosystems. - Nat. Croat. 22(1): 199-2014.

Hafner, D. \& Mirković, G. 2008: Dijatomeje sedrenih barijera rijeke Une. Zbornik radova. Međunarodna konferencija: Zaštićena područja u funkciji održivog razvoja. 533-543.

Hafner, D., Dedić, A., Sučić, Ž., Lasić, A., Stanić-Koštroman, S., Škobić, D. \& Planinić, A. 2015: Litofiti potoka Badnje, Masna luka, Blidinje. Međunarodni Znanstveni simpozij, Blidinje 2015.

Hafner, D. 1991: Floristička istraživanja mikrofita rijeke Une. Floristic Research Microphytes on the River Una. - Bilten Društva Ekol. Bosne Hercegovine, ser. B., 6: 177-185.

Hafner, D., Jasprica, N. \& Carić, M. 2013: Epiphitic diatoms on Nymphaea alba L. Leaves in a submediterranean wetland (South Bosnia and Herzegovina). - Nat. Croat. 22(2): 319-331.

Hustedt, F. 1930: Bacillariophyta (Diatomae). Die Üsserwasser-flora Mitteleuropas, 10. - Jena.

Jerković, L. 1985: Diatomophyceae nekih vodenih ekosistema. Struktura i dinamika nekih ekosistema sa visokim koncentracijama teških metala (Vareš). [Diatomophyceae some water ecosystems. Structure and dynamics selected ecosystems with high concentration heavy metals (Vareš)]. Elaborat. 1-323.

Joh, G. 2011: Algal Flora of Korea 3 (3), Chrysophyta: Bacillariophyceae: Pennales: Raphidaceae: Eunotiaceae. Freshwater Diatoms III. - Inje.

Kamberović, J. \& Barudanović, S. 2012: Algae and macrophytes of mine pit lakes in the whider area of Tuzla, Bosnia and Herzegovina. - Nat. Croat. 21(1): 101-118.

Kapetanović, T. \& Hafner, D. 2007: Diatoms of wet habitats in the subalpine belt of Mt. Vranica (Bosnia and Herzegovina). Proceedings of the 1st Central European Diatom Meeting 2007 Kusber, W.-H., \& Jahn, R. (eds). - Berlin.

Kamberović, J., Barudanović, S., Lonić, E. \& Ferizbegović, J. 2013: Biomonitoring kopovskog jezera Šićki brod u funkciji očuvanja močvarnog biodiverziteta. [Biomonitoring of the mine pit lake Šićki Brod in the function of preserving wetland biodiversity]. Zbornik radova 1. Šesti međunarodni kongres "Ekologija, zdravlj, rad, sport" Banja Luka. 537-541.

Kapetanović, T., Jahn, R., Redžić, S. \& Carić, M. 2011: Diatoms in a poor fen of Bijambare protected landscape, Bosnia and Herzegovina. - Nova Hedwigia 93(1-2): 125-151. https://doi.org/10.1127/0029-5035/2011/0093-0125

Karasuljić-Ibrović, E. 2017: Diverzitet algi na sedrenim barijerama rijeke Trebižat. [Diversity of algae on tuffa bariers in Trebižat river]. Univerzitet u Sarajevu, Prirodno-matematički fakultet. Završni-magistarski rad.

Karlinski, J. 1896: Flora kremenastih haluga ili gljivica (diatomea) u Bosni i Hercegovini. [Diatom flora in Bosnia and Herzegovina]. - Glasnik Zemaljskog Muz. Bosni Hercegovini 8(2-3): 389-409.

Krizmanić, J., Ilić, M., Vidaković, D., Subakov-Simić, G., Cvetanović, K. \& Petrović, J. 2015: New records and rare taxa of the genus Eunotia Ehrenberg (Bacillariophyceae) for the diatom flora of Serbia. - Bot. Serbica 39(1): 35-43. https://doi.org/10.2478/s13545-014-0132-0

Lange-Bertalot, H. \& Metzeltin, D. 1996. Oligotrophie-Indicatoren. 800 Taxa repräsentative für drei diverse See-Typen. - Iconogr. Diatomologica 18: 1-393.

Lange-Bertalot, H. \& Steindorf, A. 1996: Rote liste der limnischen Kieselalgen (Bacillariophyceae) Deutschlands. - Schrittenreihe Vegetationskunde 28: 633-677.

Mašić, E. 2018: Modeli restauracije kopovskih jezera u Federaciji Bosne i Hercegovine. Doktorska disertacija. 1-185. 
Lecointe, C., Coste, M. \& Prygiel, J. 1993: "OMNIDIA": a software for taxonomy, calculation of diatom indices and inventories management. - Hydrobiologia 269/270: 509-513. https://doi.org/10.1007/BF00028048

Oritz-Lerin, R. \& Cambra, J. 2007: Distribution and taxonomic notes of Eunotia Ehrenebrg 1837 (Bacillariophyceae) in rivers and streams of Northern Spain. - Limnetica 26(2): 415-434.

Pavlov, A. \& Levkov, Z. 2013: Diversity and distribution of taxa in the genus Eunotia Ehrenberg (Bacillariophyta) in Macedonia. - Phytotaxa 86(1): 1-117. https://doi.org/10.11646/phytotaxa.86.1.1

Protić, Đ. 1897: Prilozi k poznavanju kremenjašica (diatomacea) Bosne i Hercegovine. [Contributions to knowladge of diatom algae (diatomaceae) in Bosnia and Herzegovina]. Glasnik Zemaljskog Muz. Bosni Hercegovini (2): 313-325.

Protić, Đ. 1903: Peti prilog poznavanju flore okoline Vareša u Bosni. [The fifth contribution to the knowledge of the flora around Vareš in Bosnia]. - Glasnik Zemaljskog Muz. Bosni Hercegovini (2): 276-288.

Protić, Đ. 1904: Prilog k poznavanju flore kriptogama (tajnocvjetaka) okoline Sarajeva. [A contribution to the knowledge of the flora of cryptogams around Sarajevo]. - Glasnik Zemaljskog Muzeja Bosni Hercegovini (1): 61-72.

Protić, Đ. 1906: Drugi prilog k poznavanju flore resina (alge) Bosne i Hercegovine. [The second contribution to the knowledge of the flora algae of Bosne anad Herzegovina]. - Glasnik Zemaljskog Muzeja Bosni Hercegovini (1): 5-15.

Protić, Đ. 1907: Treći prilog k poznavanju flore resina (alge) Bosne i Hercegovine. [The third contribution to the knowledge of the flora algae of Bosne anad Herzegovina]. - Glasnik Zemaljskog Muzeja Bosni Hercegovini (2): 191-202.

Protić, Đ. 1908: Četvrti prilog k poznavanju flore resina (alge) Bosne i Hercegovine. [The fourth contribution to the knowledge of the flora algae of Bosne anad Herzegovina]. Glasnik Zemaljskog Muzeja Bosni Hercegovini (4): 513-523.

Protić, Đ. 1920: Novi prilozi za poznavanje flore kriptogama okoline Sarajeva. [Addimenta nova ad cognitionem florae Cryptogamarum regionis Sarajevoensis, 1. Algae / New contributions to the knowladge of the flora of cryptogams around Sarajevo]. - Glasnik Zemaljskog Muz. Bosni Hercegovini (1): 47-56.

Protić, Đ. 1921: Algae (Alge) močvare u botaničkoj bašti zemaljskog muzeja u Sarajevu. [Algae in swamp in the botanical garden of the National Museum in Sarajevo]. - Glasnik Zemaljskog Muz. Bosni Hercegovini 33-34: 33-36.

Protić, Đ. 1924: Hidrobiološke i plankton studije na jezerima Bosne i Hercegovine. [Hydrobiological and plankton study on lakes in Bosnia and Herzegovina]. - Glasnik Zemaljskog Muz. Bosni Hercegovini 34: 39-68.

Protić, Đ. 1925: Hidrobiološke i plankton studije na jezerima Bosne i Hercegovine. II dio - Glečerska jezera. [Hydrobiological and plankton study on lakes in Bosnia and Herzegovina. Part IIGlacial lakes]. - Glasnik Zemaljskog Muz. Bosni Hercegovini 37: 93-124.

Protić, Đ. 1926: Hidrobiološke i plankton-studije na jezerima Bosne i Hercegovine. III dio Glečerska jezera. [Hydrobiological and plankton study on lakes in Bosnia and Herzegovina. Part III-Glacial lakes]. - Glasnik Zemaljskog Muz. Bosni Hercegovini (1): 47-78.

Protić, Đ. 1927: Hidrobiološke i plankton-studije na jezerima Bosne i Hercegovine. IV dio Glečerska jezera. [Hydrobiological and plankton study on lakes in Bosnia and Herzegovina. Part IV-Glacial lakes]. - Glasnik Zemaljskog Muz. Bosni Hercegovini (1): 3-42.

Protić, Đ. 1928. Plankton-Studije na jezerima Zelengore u Bosni. [Plankton-Studies on lakes Zelengora in Bosnia]. - Glasnik Zemaljskog Muz. Bosni Hercegovini 40(1): 23-34.

Protić, Đ. 1928. Ždrimačka jezera - Hidrobiološka i plankton studija. [Ždrimačka lakes - Hidrobiological and plankton study]. - Glasnik Zemaljskog Muz. Bosni Hercegovini 40(1): 87-106. 
Protić, Đ. 1928. Bara Velika Tišina. Hidrobiološka i plankton-studija. [Swamp Velika Tišina. Hydrobiological and plankton study]. - Glasnik Zemaljskog Muz. Bosni Hercegovini (1): 116.

Redžić, S. 2007: Syntaxonomic diversity as an indicator of ecological diversity — case study Vranica Mts in the Central Bosnia. - Biologia 62(2): 173-184. https://doi.org/10.2478/s11756007-0026-3

Tomović, G., Sabovljević, M., Djokić, I., Petrović, P., Djordjević, V., Lazarević, P., Mašić, E., Barudanović, S., Ștefănuț, S., Niketić, M., Butorac, B., Pantović, J., Hajrudinović-Bogunić, A., Bogunić, F., Kabaš, E., Vukojičić, S., Kuzmanović, N., Djurović, S., Z. and Buzurović, U. 2020: New records and noteworthy data of plants, algae and fungi in SE Europe and adjacent regions, 2. - Bot. Serbica 44(2): 251-259. https://doi.org/10.2298/BOTSERB2002251T

Van Dam, H., Mertens, A. \& Sinkeldam, J. 1994: A coded checklist and ecological indicator values of freshwater diatoms from the Netherlands. - Netherland J. Aquatic Ecol. 28(1): 117-133. https://doi.org/10.1007/BF02334251

Addresses of the authors:

Ermin Mašićl, 2* \& Senka Barudanović ${ }^{1,2}$,

${ }^{1}$ Faculty of Science, University of Sarajevo, Zmaja od Bosne 33-35, 71000 Sarajevo, Bosnia and Herzegovina

${ }^{2}$ Center for ecology and natural resources - Academician Sulejman Redžić, Zmaja od Bosne 33-35, 71000 Sarajevo, Bosnia and Herzegovina

*Corresponding author: erminmasic@hotmail.com 
